\title{
THE FIRST TRANSPARENT FACETED GRANDIDIERITE, FROM SRI LANKA
}

\author{
By Karl Schmetzer, Murray Burford, Lore Kiefert, and Heinz-Jürgen Bernhardt
}

Gemological, chemical, and spectroscopic properties are presented for the first known transparent faceted grandidierite. This jewelry-quality $0.29 \mathrm{ct}$ stone was fashioned from rough reportedly found in the Kolonne area of Sri Lanka. The greenish blue borosilicate has refractive indices of 1.583 to 1.622 , which correlate to a low iron content of $1.71 \mathrm{wt} . \%$ $\mathrm{FeO}$ and readily separate it from the gem material closest in properties, lazulite.

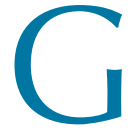
randidierite, a magnesium-aluminum borosilicate, $\mathrm{MgAl}_{3} \mathrm{BSiO}_{9}$, is mentioned only rarely as a "possible" blue gemstone (Ostwald, 1964), although the existence of faceted stones has been reported occasionally in the gemological literature (see, e.g., Mitchell, 1977). However, the samples available to date as faceted stones or cabochons, all originating from southern Madagascar, are opaque-never transparent—or at best translucent (Arem, 1987). This article describes the first transparent faceted grandidierite, which is also the first faceted grandidierite reported from Sri Lanka.

Grandidierite occurs in pegmatites, contact metamorphic rocks (hornfelses), and high-grade (granulite facies) metamorphic rocks; worldwide about 40 localities are known (Grew, 1996). Grandidierite was first discovered in a pegmatitic environment at Andrahomana near Taolanaro (formerly Fort Dauphin) in southeastern Madagascar (Lacroix, 1902, 1904). The orthorhombic mineral was named by Lacroix after Alfred Grandidier, one of the French explorers of Madagascar. Lacroix described the nontransparent material as both massive (1902) and forming crystals as long as $8 \mathrm{~cm}$ (1904). The color of grandidierite from different localities is described as blue, greenish blue, blue-green, and bluish green.

The Kolonne area of Sri Lanka, which is located approximately $8 \mathrm{~km}$ south-southeast of Rakwana, near Ratnapura, has become known for some rare gem materials such as sapphirine (Harding and Zoysa, 1990), olivine with a high iron content (Burford and Gunasekera, 2000), and-most recently-the Ca-MgAl borosilicate serendibite (Schmetzer et al., 2002). In 2000 while in Ratnapura, one of the authors (MB) purchased the grandidierite described in this article, reportedly from the Kolonne area, as an 0.85 ct crystal fragment. After faceting, the rough yielded a 0.29 ct greenish blue transparent gemstone (figure 1).

The Sri Lankan seller offered the rough gem (on the basis of its color) as a "possible serendibite." The original flat, tabular crystal did not appear to be water worn. Probably it was mined from a primary deposit, as is the case for most sapphirine from high-grade metamorphic host rocks in the Kolonne area (see again Harding and Zoysa, 1990). Based on some initial testing, the owner believed that the stone might be the rare gem mineral grandidierite and sent it to the senior author (KS) for additional tests and confirmation.

\section{MATERIALS AND METHODS}

The faceted grandidierite was tested by standard gemological methods for refractive indices, optic character, specific gravity, and fluorescence to longand short-wave ultraviolet radiation, as well as the

See end of article for About the Authors and Acknowledgments. Gems \& Gemology, Vol. 39, No. 1, pp. 32-37.

(C) 2003 Gemological Institute of America 
spectrum seen with a handheld spectroscope. We also used standard microscopic techniques to examine the internal features under different lighting conditions, both with and without immersion liquids. After some experimentation with the immersion microscope, we were able to orient the sample in such a way that, when it was rotated, we could observe the interference figures along both optic axes. This enabled direct measurement of the $2 \mathrm{~V}$ angle and determination of the orientation of the indicatrix within the cut gemstone, especially relative to the table facet, which was necessary for the determination of maximum pleochroism.

To confirm the identification indicated by the gemological properties, we scraped a minute amount of material from the girdle to conduct X-ray powder diffraction analysis with a Gandolfi camera. Given the rarity of this material, we also examined the powder pattern of a known non-gem-quality sample from Madagascar to ensure the accuracy of the pattern in the data base. To further characterize the sample, we performed quantitative chemical analysis using a Cameca Camebax SX 50 electron microprobe to obtain 15 point analyses from a traverse across the table of the gemstone.

In addition, polarized UV-Vis $(300-800 \mathrm{~nm})$ absorption spectra were recorded using a Cary 500 Scan spectrophotometer. Infrared spectroscopy was performed with a PU 9800 Fourier-transform infrared (FTIR) spectrophotometer using a diffuse reflectance device. In addition, we analyzed the sample and its solid inclusion by laser Raman microspectrometry using a Renishaw 1000 system.

\section{RESULTS}

Gemological Properties. The gemological properties of the 0.29 ct faceted sample (table 1) were consistent with grandidierite. Unlike most known grandidierites, however, this greenish blue stone was transparent with only a few inclusions. On the basis of interference figures, the optic axes were found to be at inclinations of about $5^{\circ}$ and $20^{\circ}$, respectively, to the girdle of the stone. Consequently, with the known orientation of the indicatrix in grandidierite $(\mathrm{a}=\mathrm{X}, \mathrm{b}=\mathrm{Z}, \mathrm{c}=\mathrm{Y})$, it was established that the table is roughly parallel to the crystallographic (010) plane. Given this established orientation, the pleochroic colors of both X (greenish blue) and Y (very pale yellow, almost colorless) can be observed in a view perpendicular to the table facet, while the $\mathrm{Z}$ color (bluegreen) is visible parallel to the table of the stone (that

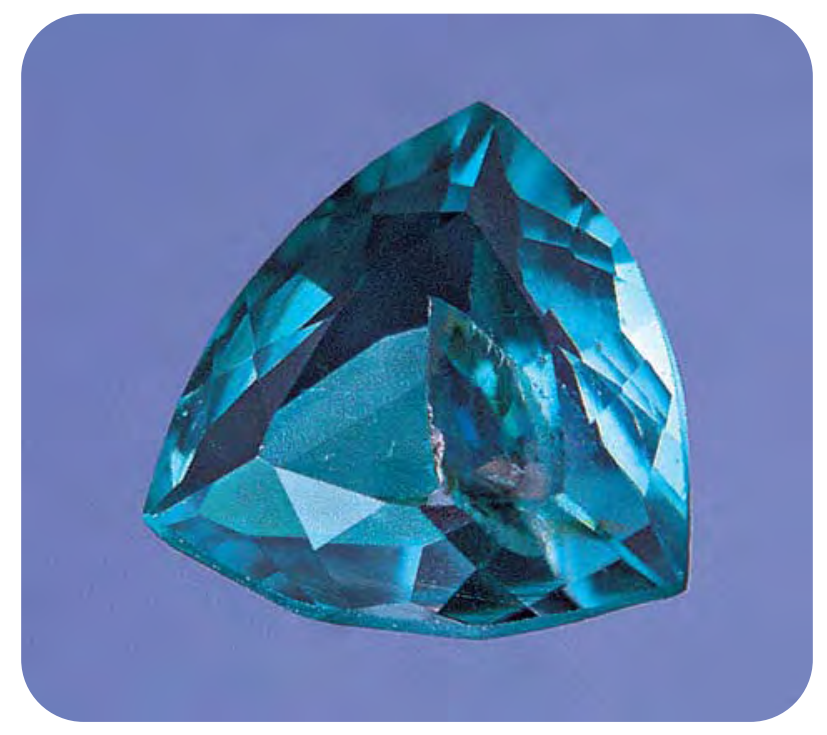

Figure 1. This $0.29 \mathrm{ct}$ grandidierite is the first known transparent faceted sample of this material and the first gem-quality sample from Sri Lanka. Photo by Maha Tannous.

is, along the girdle). The measured optic axis angle $2 \mathrm{~V}_{\mathrm{x}}$ is in good agreement with the value we calculated from the measured refractive indices.

TABLE 1. Gemological properties of the $0.29 \mathrm{ct}$ transparent faceted grandidierite from Sri Lanka.

\begin{tabular}{ll}
\hline Property & \multicolumn{1}{c}{ Description } \\
\hline Weight & $0.29 \mathrm{ct}$ \\
Size & $4.82 \times 4.63 \times 2.23 \mathrm{~mm}$ \\
Clarity & Transparent \\
Color & Greenish blue \\
Pleochroism (strong) & Greenish blue \\
$\mathrm{X}$ & Very pale yellow, almost colorless \\
$\mathrm{Y}$ & Blue-green \\
$\mathrm{Z}$ & \\
Refractive indices & $1.583 \pm 0.002$ \\
$\mathrm{n}_{\mathrm{x}}$ & $1.620 \pm 0.002$ \\
$\mathrm{n}_{\mathrm{y}}$ & $1.622 \pm 0.002$ \\
$\mathrm{n}_{\mathrm{z}}$ & 0.039 \\
Birefringence & Biaxial negative \\
Optic character & \\
Optic axis angle & $25^{\circ} \pm 3^{\circ}$ \\
$2 V_{\mathrm{x}}$ (meas.) & $25.7^{\circ}$ \\
$2 \mathrm{~V}_{\mathrm{x}}$ (calc.) & $2.96 \pm 0.02$ \\
Specific gravity & \\
UV fluorescence & Inert \\
long-wave & Inert \\
short-wave & Line at 479 nm \\
Handheld spectroscope & Parallel growth planes in two \\
Microscopic features & directions; needle-like channel, \\
& partly filled with polycrystalline, \\
& birefringent matter; small fractures \\
& \\
\hline &
\end{tabular}




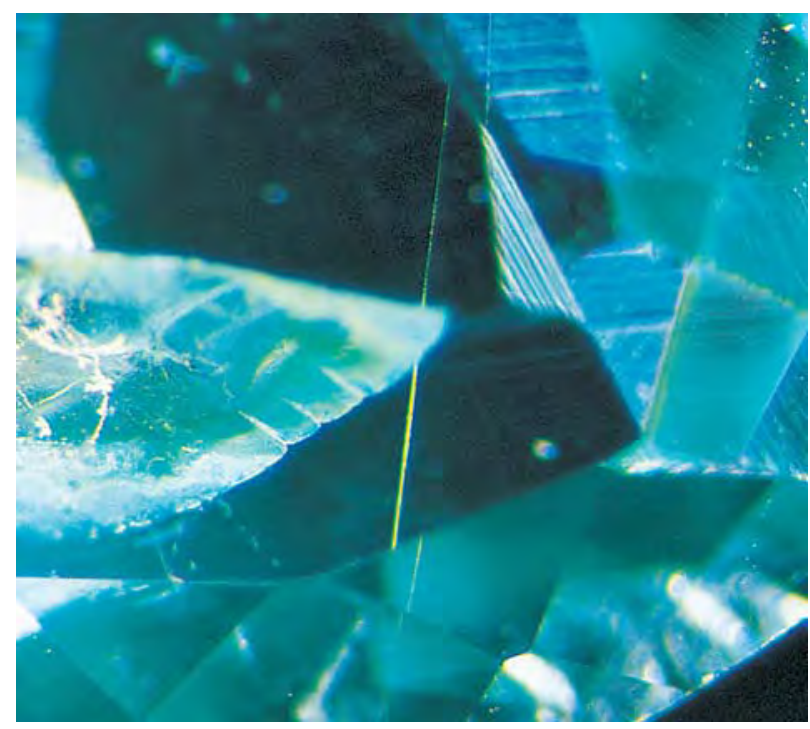

Figure 2. This needle-like channel in the faceted grandidierite from Sri Lanka is filled with a polycrystalline material. Unfortunately, there was not a sufficient amount of this polycrystalline material to identify it by Raman analysis. Note also, to the left, one of two fractures seen in the stone. Photomicrograph by $H$. A. Hänni; magnified 40×.

Features Observed with the Microscope. The sample revealed two series of parallel growth planes, but no distinct color zoning was associated with this growth pattern. The grandidierite was slightly included: One needle-like channel, partly filled with a polycrystalline birefringent material (figure 2), was observed, as were two unhealed fractures (see, e.g., figure 2). Raman analysis provided no identification for the polycrystalline material.

X-ray Diffraction Analysis. The X-ray powder diffraction pattern of the faceted stone was consistent with the published pattern for grandidierite (see, e.g., McKie, 1965) and the pattern of our own control sample from Madagascar.

Chemical Composition. The electron microprobe results are averaged in table 2; no chemical zoning was evident from the 15 points analyzed. Only 1.71 wt. \% FeO (average) was measured, and traces of chromium also were present.

Spectroscopic Properties. UV-Visible. Due to the crystallographic orientation of the faceted grandidierite, we could record polarized spectra only perpendicular to the table facet. With this orientation, we obtained spectra parallel to X (greenish blue) and $\mathrm{Y}$ (very pale yellow), as illustrated in figure 3 . The spectrum parallel to $\mathrm{X}$ reveals a strong absorption band in the red at about $737 \mathrm{~nm}$ and an increasing absorption from the greenish blue minimum to the UV range. The Y spectrum consists of an increasing absorption from the red to the blue and ultraviolet range. In both spectra, as labeled in figure 3, several small absorption bands are found in the visible and ultraviolet range, with the most distinctive band at $479 \mathrm{~nm}$ in the Y spectrum, which also can be seen with a handheld spectroscope.

Infrared and Raman. The nonpolarized infrared spectrum showed several absorption maxima in the $4000-2000 \mathrm{~cm}^{-1}$ range (figure 4). Below $2000 \mathrm{~cm}^{-1}$, the general absorption was too strong to record a spectrum of usable quality. The Raman spectrum consisted of numerous lines in the $200-1200 \mathrm{~cm}^{-1}$ range, the strongest of which occurred at 492, 659, 717, 868, 952, 982 , and $993 \mathrm{~cm}^{-1}$ (figure 5).

\section{DISCUSSION}

The chemical composition of our faceted sample from Sri Lanka is consistent with the theoretical

TABLE 2. Chemical composition of a gem-quality grandidierite from Sri Lanka.

\begin{tabular}{lr}
\multicolumn{2}{c}{ Oxides (wt. \%) } \\
$\mathrm{SiO}_{2}$ \\
$\mathrm{TiO}_{2}$ & 20.20 \\
$\mathrm{Al}_{2} \mathrm{O}_{3}$ & 0.01 \\
$\mathrm{~B}_{2} \mathrm{O}_{3}{ }^{\mathrm{b}}$ & 52.64 \\
$\mathrm{Cr}_{2} \mathrm{O}_{3}$ & 11.91 \\
$\mathrm{~V}_{2} \mathrm{O}_{3}$ & 0.07 \\
$\mathrm{FeO}^{\mathrm{C}}$ & 0.01 \\
$\mathrm{MnO}$ & 1.71 \\
$\mathrm{MgO}$ & 0.03 \\
$\mathrm{CaO}$ & 12.85 \\
$\mathrm{Total}$ & 0.01 \\
\hline
\end{tabular}

Cations per 9 oxygens

$\begin{array}{lc}\mathrm{Si} & 0.983 \\ \mathrm{Ti} & - \\ \mathrm{Al} & 3.017 \\ \mathrm{~B} & 1.000 \\ \mathrm{Cr} & 0.002 \\ \mathrm{~V} & - \\ \mathrm{Fe} & 0.070 \\ \mathrm{Mn} & 0.001 \\ \mathrm{Mg} & 0.932 \\ \mathrm{Ca} & 0.001\end{array}$

a Electron microprobe analysis, average of 15 point analyses.

$b$ Calculated for $B=1.000$, according to the theoretical formula $\mathrm{MgAl}_{3} \mathrm{BSiO}_{9}$.

c Total iron as FeO. 
formula for grandidierite, $\mathrm{MgAl}_{3} \mathrm{BSiO}_{9}$ or $(\mathrm{Mg}$, $\mathrm{Fe}^{2+} \mid \mathrm{Al}_{3} \mathrm{BSiO}_{9}$. The analytical data for this sample (again see table 2), as has been reported for translucent low-iron-bearing grandidierite from Madagascar (see table 3), indicate some replacement of magnesium by iron. In this mineral, only smaller fractions of its iron content are found as $\mathrm{Fe}^{2+}$ in $\mathrm{Al}$ sites, with minor $\mathrm{Fe}^{3+}$ also present in the $\mathrm{Mg}$ and/or $\mathrm{Al}$ sites (Stephenson and Moore, 1968; Seifert and Olesch, 1977; Qiu et al., 1990; Farges, 2001; Wilke et al., 2001).

The refractive indices of grandidierite and ominelite $\left(\mathrm{Fe}^{2+}, \mathrm{Mg}\right) \mathrm{Al}_{3} \mathrm{BSiO}_{9}$ - the recently described Fe analogue of grandidierite (Hiroi et al., 2002)—are closely related to the iron content; with increasing $\mathrm{Fe}$, the R.I. also increases (table 3). With increasing iron values, specific gravity in grandidierite also increases, from 2.91 to 2.99 (Olesch and Seifert,

Figure 3. Absorption spectra of the grandidierite in the $U V$-Vis range parallel to $X$ (greenish blue) and $Y$ (very pale yellow) show a strongly polarized absorption band in the red and several other weak absorption bands.

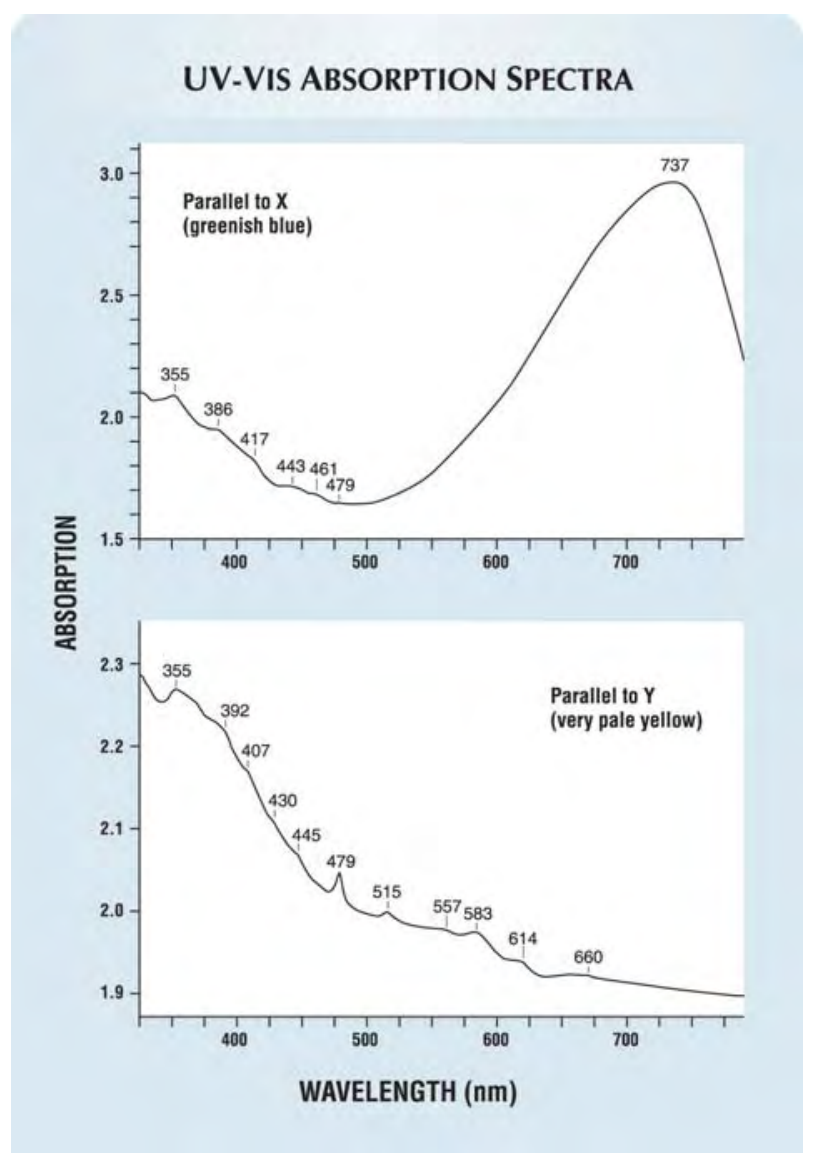

\section{FTIR SPECTRUM}

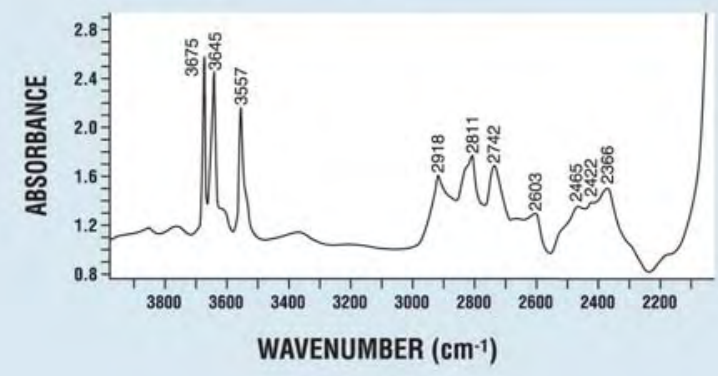

Figure 4. The nonpolarized infrared spectrum of the grandidierite shows numerous bands that are characteristic of this mineral.

1976). The properties of our faceted sample fit within this trend.

The material described by Lacroix was relatively rich in iron (with $\mathrm{FeO}$ above $10 \mathrm{wt} . \%$ ) and had refractive indices of $\mathrm{n}_{\mathrm{x}} 1.6018$ and $\mathrm{n}_{\mathrm{z}} 1.6385$. Grandidierite samples from other localities in southern Madagascar, on the other hand, had lower iron contents (1-5 wt.\% FeO) and, accordingly, lower refractive indices of $\mathrm{n}_{\mathrm{x}} 1.580-1.590$ and $\mathrm{n}_{\mathrm{z}}$ 1.620-1.629 (McKie, 1965; von Knorring et al., 1969; Black, 1970). These data are more consistent with the values mentioned for the semitransparent gem material reported to date (Mitchell, 1977; Arem, 1987; see also Farges, 2001).

Figure 5. The Raman spectrum of the transparent grandidierite from Sri Lanka also revealed several bands that appear to be characteristic of this rare gem material.

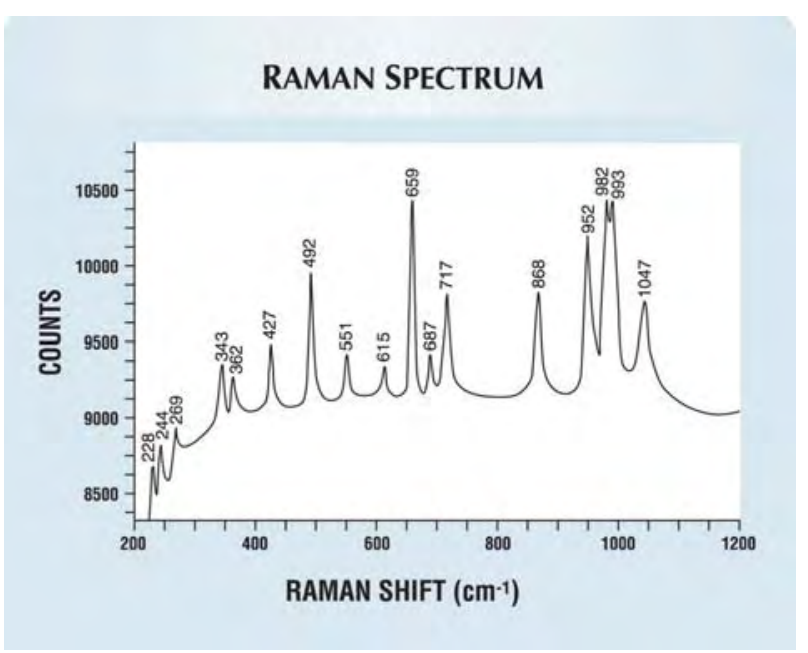


The pleochroism of grandidierite is described in numerous papers (see, e.g., the references cited in table 3) as $\mathrm{X}=$ blue, greenish blue, or blue-green; $\mathrm{Y}=$ colorless; and $\mathrm{Z}=$ greenish blue, blue-green, or green. The pleochroism of our faceted sample is consistent with this general description, except that $\mathrm{Y}$, which is colorless in thin section, appears pale yellow in thicker samples such as ours.

Rossman and Taran (2001) described polarized absorption spectra in the visible-to-infrared range for grandidierite from Metroka, Madagascar, that contained $1.10 \mathrm{wt}$.\% FeO. Four strongly polarized absorption bands in the visible and near-infrared regions were measured and assigned to $\mathrm{Fe}^{2+}$ in five-fold magnesium coordination. Two of the three spectra illustrated in that article are identical to the two spectra recorded on our Sri Lankan sample: Our X spectrum (greenish blue) is identical to the a spectrum, and our Y spectrum (slightly yellowish) is identical to the $g$ spectrum in the article cited. (According to G. Rossman [pers. comm., 2002], the labels for b and $g$ were inadvertently transposed in that article; thus, our Y spectrum is identical to the spectrum he and Taran recorded for b. Corrected spectra appear at http://minerals.gps.caltech.edu/files/visible/grandidierite.)

No detailed assignment of the smaller absorption bands was possible, but as discussed above they most likely are caused by $\mathrm{Fe}^{2+}$ or $\mathrm{Fe}^{3+}$ in the $\mathrm{Mg}$ and/or $\mathrm{Al}$ sites of the grandidierite structure.

Infrared spectra in the $1500-400 \mathrm{~cm}^{-1}$ range for grandidierite were described by von Knorring et al. (1969) and Povarennykh (1970). At present, however, no detailed interpretation of our spectra in the $4000-2000 \mathrm{~cm}^{-1}$ range is available, although there is always the possibility of impurities in the stone and small amounts of water in the structure.

The strongest lines in our Raman spectrum resemble the most characteristic lines in the Raman spectrum pictured by Maestrati (1989) for a grandidierite sample from Madagascar, but no detailed assignment of Raman bands was performed in that article. However, reference to both types of spectra, infrared and Raman, may be helpful for the identification of grandidierite.

There is almost no gem material known to date that might be mistaken for grandidierite. The closest-in terms of color, optical properties, and specific gravity-is low-iron-bearing lazulite, but this gem material always has somewhat higher refractive indices, with $\mathrm{n}_{\mathrm{x}}$ above 1.600 .

The Kolonne area in Sri Lanka is known to contain high-grade metamorphic rocks (Harding and Zoysa, 1990). Serendibite was also recently described from Kolonne as a new gem material (Schmetzer et al., 2002), and is another mineral typically formed in high-grade (granulite facies) metamorphic rocks. Previously, these two boron-bearing silicates were found in the same geographic area at only three localities (two in the U.S. and one in Madagascar: Grew et al., 1990, 1991; Nicollet, 1990). However,

TABLE 3. Refractive indices and iron content of grandidierite and ominelite from various localities. ${ }^{a}$

\begin{tabular}{|c|c|c|c|c|c|c|}
\hline Locality & $n_{x}$ & $\mathrm{n}_{\mathrm{y}}$ & $\mathrm{n}_{\mathrm{z}}$ & $\left(n_{x}+n_{y}+n_{z}\right) / 3^{b}$ & $\begin{array}{l}\mathrm{FeO}^{\mathrm{c}} \\
\text { (wt.\%) }\end{array}$ & Reference \\
\hline Synthetic & $\mathrm{nr}$ & $\mathrm{nr}$ & $\mathrm{nr}$ & 1.603 & 0 & Olesch and Seifert (1976) \\
\hline Fort Dauphin, Madagascar & 1.580 & 1.619 & 1.620 & 1.606 & 1.0 & von Knoring et al. (1969) \\
\hline Vohiboly, Madagascar & 1.587 & 1.618 & 1.622 & 1.609 & 1.1 & Black (1970) \\
\hline Kolonne, Sri Lanka & 1.583 & 1.620 & 1.622 & 1.608 & 1.71 & This study \\
\hline Sakatelo, Madagascar & 1.590 & 1.618 & 1.623 & 1.610 & 3.59 & McKie (1965) \\
\hline Cuvier Island, New Zealand & 1.590 & 1.624 & 1.628 & 1.614 & 4.7 & Black (1970) \\
\hline Ampamatoa, Madagascar & 1.590 & 1.626 & 1.629 & 1.615 & 5.0 & Black (1970) \\
\hline Cuvier Island, New Zealand & 1.593 & 1.628 & 1.633 & 1.618 & 6.7 & Black (1970) \\
\hline Rhodesia & $\mathrm{nr}$ & $\mathrm{nr}$ & $\mathrm{nr}$ & 1.622 & 6.93 & $\begin{array}{l}\text { Olesch and Seifert (1976); } \\
\text { Seifert and Olesch (1977) }\end{array}$ \\
\hline Mt. Amiata, Italy & 1.5982 & 1.6290 & 1.6346 & 1.621 & 7.75 & Van Bergen (1980) \\
\hline Andrahomana, Madagascar & 1.6018 & 1.6360 & 1.6385 & 1.625 & 10.80 & Lacroix (1904) \\
\hline Tenkawa, Japan & 1.631 & 1.654 & 1.656 & 1.647 & 19.37 & Hiroi et al. (2002) \\
\hline
\end{tabular}

a All data are for grandidierite, $\left(\mathrm{Mg}, \mathrm{Fe}^{2+}\right) \mathrm{Al}_{3} \mathrm{BSiO}_{9}$, except Hiroi et al. (2002) for ominelite, $\left(\mathrm{Fe}^{2+}, \mathrm{Mg}^{2} \mathrm{Al}_{3} \mathrm{BSiO}_{9}\right.$, the $\mathrm{Fe}$ analogue of grandidierite. Abbreviation: $\mathrm{nr}=$ not reported.

${ }^{b}$ Calculated average refractive index; see also Olesch and Seifert (1976).

c Total iron calculated as FeO. 
the two minerals occur together in the same rock at only one locality (Adirondack Mountains, Russell, New York; Grew et al., 1990).

\section{CONCLUSION}

The first known transparent faceted grandidierite, reportedly from the Kolonne area of Sri Lanka, is characterized with regard to gemological, chemical, and spectroscopic properties. The relatively low refractive indices (1.583-1.622) are related to the relatively low iron content of the sample (1.71 wt.\% $\mathrm{FeO}$. Previously, only semitransparent material from Madagascar had been described in gemological publications. With the data presented, this material is readily identifiable by standard gemological methods.
ABOUT THE AUTHORS

Dr. Schmezer (SchmetzerKarl@hotmail.com) is a research scientist residing in Petershausen, near Munich, Germany. Mr. Burford is a gemologist and dealer in rare gems who lives in Victoria, British Columbia, Canada. Dr. Kiefert is a research scientist and director of the Colored Stone Department at the SSEF Swiss Gemmological Institute, Basel. Dr. Bermhardt is head of the central electron microprobe facility at Ruhr-University, Bochum, Germany.

ACKNOWLEDGMENTS: The authors are grateful to Dr. O. Medenbach of Ruhr-University, Bochum, Germany, for performing $X$-ray diffraction, and to $P$. Giese of SSEF for his assistance recording various spectra. Dr. H. A. Hänni of SSEF critically reviewed the original manuscript.

\section{REFERENCES}

Arem J.E. (1987) Color Encyclopedia of Gemstones, 2nd ed. Van Nostrand Reinhold Co., New York.

Black P.M. (1970) Grandidierite from Cuvier Island, New Zealand. Mineralogical Magazine, Vol. 37, No. 289, pp. 615-617.

Burford M., Gunasekera D.P. (2000) An unusual olivine group gemstone from the Kolonne area, Sri Lanka. Canadian Gemmologist, Vol. 21, No. 3, pp. 84-90.

Farges F. (2001) Crystal chemistry of iron in natural grandidierites: An X-ray absorption fine-structure spectroscopy study. Physics and Chemistry of Minerals, Vol. 28, No. 9, pp. 619-629.

Grew E.S. (1996) Borosilicates (exclusive of tourmaline) and boron in rock-forming minerals in metamorphic environments. In E. S. Grew and L. M. Anovitz, Eds., Reviews in Mineralogy, Vol. 33: Boron. Mineralogy, Petrology and Geochemistry, Mineralogical Society of America, Washington, DC, pp. 387-502.

Grew E.S., Yates M.G., DeLorraine W. (1990) Serendibite from the northwest Adirondack lowlands, in Russell, New York, USA. Mineralogical Magazine, Vol. 54, No. 374, pp. 133-136.

Grew E.S., Yates M.G., Swihart G.H., Moore P.B., Marquez N. (1991) The paragenesis of serendibite at Johnsburg, New York, USA: An example of boron enrichment in the granulite facies. In L. L. Perchuk, Ed., Progress in Metamorphic and Magmatic Petrology, Cambridge University Press, Cambridge, England, pp. 247-285.

Harding R.R., Zoysa E.G. (1990) Sapphirine from the Kolonne area, Sri Lanka. Journal of Gemmology, Vol. 22, No. 3, pp. 136-140.

Hiroi Y., Grew E.S., Motoyoshi Y., Peacor D.R., Rouse R.C., Matsubara S., Yokoyama K., Miyawaki R., McGee J.J., Su S.C., Hokada T., Furukawa N., Shibasaki H. (2002) Ominelite, $(\mathrm{Fe}, \mathrm{Mg}) \mathrm{Al}_{3} \mathrm{BSiO}_{9}\left(\mathrm{Fe}^{2+}\right.$ analogue of grandidierite), a new mineral from porphyritic granite in Japan. American Mineralogist, Vol. 87, No. 1, pp. 160-170.

Lacroix A. (1902) Note préliminaire sur une nouvelle espèce minérale. Bulletin de la Société Française de Minéralogie, Vol. 25, No. 4, pp. 85-86.

Lacroix A. (1904) Sur la grandidiérite. Bulletin de la Société Française de Minéralogie, Vol. 27, No. 9, pp. 259-265.

Maestrati R. (1989) Contributions à l'édification du catalogue Raman des gemmes. Diplôme d'Université de Gemmologie, Université de Nantes.
McKie D. (1965) The magnesium aluminium borosilicates: Kornerupine and grandidierite. Mineralogical Magazine, Vol. 34, No. 268, pp. 346-357.

Mitchell R.K. (1977) African grossular garnets; blue topaz; cobalt spinel; and grandidierite. Journal of Gemmology, Vol. 15, No. 7, pp. 354-358.

Nicollet C. (1990) Occurrences of grandidierite, serendibite and tourmaline near Ihosy, southern Madagascar. Mineralogical Magazine, Vol. 54, No. 374, pp. 131-133.

Olesch M., Seifert F. (1976) Synthesis, powder data and lattice constants of grandidierite, $(\mathrm{Mg}, \mathrm{Fe}) \mathrm{Al}_{3} \mathrm{BSiO}_{9}$. Neues Jahrbuch für Mineralogie Monatshefte, Vol. 1976, No. 11, pp. 513-518.

Ostwald J. (1964) Some rare blue gemstones. Journal of Gemmology, Vol. 9, No. 5, pp. 182-184.

Povarennykh A.S. (1970) Spectres infrarouges de certains minéraux de Madagascar. Bulletin de la Société Française de Minéralogie et de Cristallographie, Vol. 93, No. 2, pp. 224-234.

Qiu Z.-M., Rang M., Chang J.-T., Tan M.-J. (1990) Mössbauer spectra of grandidierite. Chinese Science Bulletin, Vol. 35, No. 1, pp. 43-47.

Rossman G.R., Taran M.N. (2001) Spectroscopic standards for four- and five-coordinated $\mathrm{Fe}^{2+}$ in oxygen-based minerals. American Mineralogist, Vol. 86, No. 7-8, pp. 896-903.

Schmetzer K., Bosshart G., Bernhardt H.-J., Gübelin E.J., Smith C.P. (2002) Serendibite from Sri Lanka. Gems \&) Gemology, Vol. 38, No. 1, pp. 73-79.

Seifert F., Olesch M. (1977) Mössbauer spectroscopy of grandidierite, $(\mathrm{Mg}, \mathrm{Fe}) \mathrm{Al}_{3} \mathrm{BSiO}_{9}$. American Mineralogist, Vol. 62, No. 5-6, pp. 547-553.

Stephenson D.A., Moore P.B. (1968) The crystal structure of grandidierite, $(\mathrm{Mg}, \mathrm{Fe}) \mathrm{Al}_{3} \mathrm{SiBO}_{9}$. Acta Crystallographica, Vol. B24, No. 11, pp. 1518-1522.

Van Bergen M.J. (1980) Grandidierite from aluminous metasedimentary xenoliths within acid volcanics, a first record in Italy. Mineralogical Magazine, Vol. 43, No. 329, pp. 651-658.

von Knorring O., Sahama Th.G., Lehtinen M. (1969) A note on grandidierite from Fort Dauphin, Madagascar. Bulletin of the Geological Society of Finland, Vol. 41, pp. 71-74.

Wilke M., Farges F., Petit P.-E., Brown G.E. Jr., Martin F. (2001) Oxidation state and coordination of Fe in minerals: A Fe KXANES spectroscopic study. American Mineralogist, Vol. 86, No. 5-6, pp. 714-730. 
sure and environment. In the third method, small cut stones develop graphitic products as a result of the high temperatures induced during fashioning. The fourth method subjects larger diamonds to ion beam techniques, usually accompanied by heating. All these processes may produce glassy deposits in fractures and cavities on the diamonds, as well as synthetic carbons, frequently as films, on the surface.

These treatments can be identified by conventional microscopy combined with strong lighting or luminescence. Raman spectrometry is helpful in identifying the different types of carbon in these diamonds. Diamonds with graphite on the surface can be recognized with the aid of a thermal-type diamond tester.

Change of colour produced in natural brown diamonds by HPHT-processing. V. G. Vins, Proceedings of the Russian Mineralogical Society, Vol. 131, No. 4, 2002, pp. 111-117 [in Russian with English abstract].

The change in color produced by high pressure-high temperature (HPHT) processing of natural brown diamonds at 5.0-6.0 GPa and 2,100-2,300 K has been investigated by absorption spectroscopy in the UV, visible, and IR ranges. Such treatment of type IIa brown diamonds makes them colorless, but occasionally they acquire a light pink color. Type Ia brown diamonds change to bright yellow-green of various tints. The depth of color, as well as the relative strength of the yellow and green hues, depends on the absorption intensity of $\mathrm{N} 3, \mathrm{H} 4, \mathrm{H} 3$, and $\mathrm{H} 2$ nitrogenvacancy centers formed during the HPHT treatment. It is concluded that annealing of plastic deformation takes place during the HPHT treatment and thus the density of dislocations decreases. The energy activating the dislocation movement via plastic deformation is $6.4 \mathrm{eV}$. Models of the color-center transformations are discussed, and color photos of diamonds faceted after HPHT processing are presented.

$R A H$

Change of colour produced in synthetic diamonds by bHT-processing. V. Vins, Gemological Bulletin (Gemological Society of Russia), No. 5, 2002, pp. 26-32.

Changes in types IIa and $\mathrm{Ib}$, and subtypes IaB and IbA, synthetic diamonds on bHT-processing (exposure to fast-electron irradiation and subsequent high-temperature annealing) are described. Some observations about synthetic diamonds subjected to this treatment include: A lower growth rate results in fewer impurity defects; synthetic diamonds grown at various temperatures display different optically active defects, including color centers; an increase in growth temperature results in a gradual change of the synthetic diamond type $(\mathrm{Ib} \rightarrow \mathrm{IaB} \rightarrow \mathrm{IbA} \rightarrow \mathrm{IaA})$ and sharp color zoning in the synthetic diamond crystal; nitrogen-nickel-vacancy defect formation (and sometimes resultant photoluminescence) may be induced in synthetic diamonds by HPHT processing.
[Editor's note: An earlier paper on $\beta$ HT-processing of natural diamonds by the same author, including details of the process, was abstracted in Fall 2002 Gems e) Gemology, p. 288.]

CT

Investigation of radiation-induced yellow color in tourmaline by magnetic resonance. K. Krambrock, M. V. B. Pinheiro, S. M. Medeiros, K. J. Guedes, S. Schweizer, and J.-M. Spaeth, Nuclear Instruments and Methods in Physics Research B, Vol. 191, No. 1-4, 2002, pp. 241-245.

The cause of the yellow color produced by $\gamma$-irradiation of colorless Li-bearing tourmaline (elbaite) from Minas Gerais, Brazil, was determined by electron paramagnetic resonance (EPR) and electron nuclear double resonance (ENDOR) techniques.

Two paramagnetic centers (I and II) are present. Center II is identified as an $\mathrm{H}^{0}$ electron trap. The identification of center $\mathrm{I}$ is not as direct and is proposed to be an $\mathrm{Al}^{-\mathrm{O}^{-}} \mathrm{-Al}$ hole trap. Both centers are stable up to $250^{\circ} \mathrm{C}$. It is suggested that the $\mathrm{O}^{-}$hole trap is responsible for the yellow color, with an optical absorption band centered around $3.4 \mathrm{eV}$ and a tail extending into the visible range of the spectrum. $A I$

\section{MISCELLANEOUS}

Closing the gender gap. R. Bates, JCK, Vol. 173, No. 8, 2002, pp. 65-66.

It is ironic that even though most of the products of the jewelry trade are bought and worn by women, the industry is dominated by men. However, this is changing. Women have a large and growing presence in certain sectors of the industry, namely retail, design and fashion, and public relations. Conversely, men dominate the watch, gemstone, and manufacturing sectors, and there is relatively little female involvement in the diamond trade, which is the most tradition-bound branch of the industry.

Much of the credit for the increased visibility and advancement of women in the jewelry trade deservedly goes to the Women's Jewelry Association (WJA). It was organized in the early 1980s mainly to give women a place to network but also as a response, in part, to the fact that other organizations in the industry were male dominated. WJA has since grown to more than 1,000 members and now welcomes men as full-fledged members.

Even with recent advances, some feel that the trade is still significantly behind the times when it comes to gender equality. But the once-homogenous (i.e., overwhelmingly male) industry is moving inexorably forward with respect to gender issues. Recent demographics show that more women are interested in entering the trade than men; for example, $60 \%$ of the resident students at GIA are women. Eventually this will result in a closing of the gender gap, as it has in many other industries and professions where ability and performance are the main criteria for success.

$A A L$ 